\title{
MANAgINg GREEN Supply Chain: INITIATIVES AND OUTCOMES
}

\author{
Dr.P.Lakshmi ${ }^{*}$ and S.Visalakshmi * \\ *Department of Management Studies, National Institute of Technology,Tiruchirappalli, \\ plakshmi@nitt.edu visa.sregmail.com
}

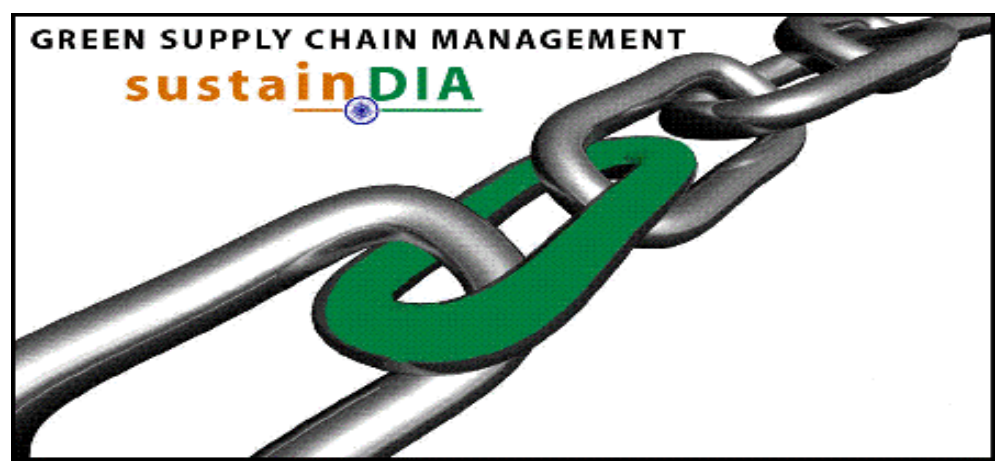

\section{ABSTRACT}

Reacting to increasingly stringent government regulations and rising consumer demands for more sustainable products, and also to create competitive advantages, many companies have begun implementing sustainability practices in their strategy and everyday management. Not many studies are done in the area of environment friendly supply chain practices adopted by large corporate houses across the globe. Due to their enormous economic and environmental impact on society with their extensive networks of suppliers and customers, understanding their sustainability related eco friendly supply chain practices, will help us identify the trends in corporate sustainability management and fill the gap between theory and practice. The intention of this research is to identify the sustainable supply chain management practices adopted by the world's largest corporations. Case studies on green strategies adopted by Hewlett Packard, Coca Cola, Dutch flower industry and Bank of America and how they have made huge profits as well as have brought an even greater impact on the environment has been included in this paper. The research also throws light on the initiatives taken in this field by Indian companies and how a major progress can be driven in this perspective

\section{KEYWORDS}

Green Supply chain management, Sustainability, Going Green, Product Development

\section{INTRODUCTION}

"GSCM is defined as integrating environmental thinking into supply chain management, including product design, material sourcing and selection, manufacturing processes, delivery of the final product to the consumers, and end-of-life management of the product after its useful life". (Srivastava, 2007).

Environmental responsibility has evolved as a business imperative as it aids companies to attain their business objectives. In the recent past sustainability has gradually moved from the periphery to the core of business. Companies are taking on sustainability practices for a variety of reasons based on the industries and regions in which they operate.

GSCM improves operations by employing an environmental solution:

DOI: $10.5121 /$ ijmvsc.2012.3405 
$\checkmark$ Improves agility - GSCM helps to mitigate risk and speeds up innovations;

$\checkmark$ Increases adaptability - green supply chain analysis often leads to innovative processes and continuous improvements;

$\checkmark$ Promotes alignment - GSCM involves negotiating policies with suppliers and customers, which results in better alignment of business processes and principles;

\section{DRIVERS OF GREEN SUPPLY CHAIN MANAGEMENT}

The main reasons for adapting GSCM are:

Financial benefit: Low-carbon means low-energy and thereby lowers cost. Companies can make lot of money by saving energy.

Employee engagement: Employees understand the fact that working environment friendly ways is the right thing to do. Hence, they always stay engaged and support such activities.

Customer demand: Consumers and businesses have started asking questions on the production processes whether they adopt environment friendly ways. Aware consumers strongly support societal benefits.

Risk management: Future needs require equal attention and producers do consider that. Long term goals and green supply chain holds a lot of importance for a long life of any company. (Source: CSCMP India 2012 Conference)

\subsection{GSCM- Short-term forces:}

- Demand for greener commodities: Consumer demand for eco friendly goods is increasing. A large number of customers prefer companies that have superior environmental records and greener products and are ready to pay a premium for it.

- Legal policies: New government policies are eliminating merchandise made from environmentally vicious materials and polluting methods. It has become significant for the companies to abide by the policies of the respective countries. E.g. Europe has constrained the goods containing ecologically unsafe substances like lead, mercury, and cadmium and chromium.

- Financial competitiveness: Implementation of green values and paramount practices like recycling, reducing energy consumption etc. can drastically reduce the cost and progress operational capability. Rising cost and escalating demand of fuel is further acting like a motivation for execution of green supply chain management.

\subsection{GSCM- Long-term forces:}

1) Affordability of the environment: It is the maximum number of creatures of a specified species that an environment can sustain over the long term. Excess utilization causes early exhaustion of resources.

2) Eco-space: Sustainable equilibrium between human activities and the environment is characterized by constant population, capital stocks and rate of material throughput.

3) "Factor Four" concept: Resource yield should be quadrupled so that wealth is doubled and resource utilisation is halved.

4) Environmental liability: It is the costs of refurbishing prior environmental injury as well as the cost of recurring refurbish measures. Unless efforts are taken to diminish environmental degradation, environmental liability continues to augment and the burden is shifted to future generations.

5) Inter-generational veracity: There should be fair play between people alive today and future generations. The connotation is that unsustainable production and consumption by today's 
society will deplete the ecological, social, and economic foundation for tomorrow's society, whereas sustainability efforts ensure that future generations will have the means to obtain a quality of life equal to or better than today's.

6) Intra-generational veracity: There should be fairness between different groups of people alive today. Similar to inter-generational veracity, intra-generational veracity entails that consumption and production in one community should not demoralize the ecological, social, and economic basis for other communities to preserve or advance their quality of life.

\section{GOING GREEN- ESTABLISHED AND EFFECTUAL STEP TOWARDS A 'GREEN' WAY}

For majority of the companies, the path to sustainability commences with the supply chain. The supply chain is where companies shift things, build things, accumulate things, and chuck things away. It is a vital part of an organization's environmental footprint. Green supply chain management - the combination of both environmental and supply chain management - is an established step to improve business performance while condensing the company's impact on the environment.

Green Vision: The green revelation sets off with customer needs and comprises green programs the purchaser is prepared to pay for. A company's internal business approach is then applied to recognize the task of environmental stewardship. The overall approach is brought together by needs for green procedures from stakeholders, which comprises supervisory body, shareholders and the society at large. For example, two concerns, Timberland and Herman Miller both have an environment friendly business ethnicity; disparities in their business approach effect in different green supply chain visions. Herman Miller's customers are more stimulated by lesser cost; as an outcome, Herman Miller's green supply chain approach is geared toward programs that have least impact on product price. In contrast, Timberland sells products for outdoor enthusiasts, an environmentally mindful customer fragment. As a result, the environmental impacts of its products occupy a major part in their product strategy.

1) Environment friendly product categories: Considering the product's contents permit companies to recognize the product's environmental impact as it passes through its life cycle. It entails sorting out of materials by the type of impact it creates-recyclability, human health risk, etc and by the enormity of that impact. For example, Hewlett Packard's product stewards leverage industry standards for product substance and environmental finest practices to boost green designs.

2) Following the Product: Despite the fact that a product's materials have inherent environmental impacts, the supply chain creates further intricacies. Scheming the supply chain recognizes the concerned players and processes and their impact on the environment. It also identifies key associates for employing green supply chain initiatives. Preferably, the complete product life cycle would be recognized, from raw material procurement and transportation to final customer use and removal. This process can disclose gaps in knowledge about a company's supply chain, particularly in phases beyond the company's direct contact. The shaped supply chain scheme can then identify energy consumed, waste and emissions produced at every step in the product's life cycle. For example, surplus packaging diminishes the quantity shipped per shipment, increases the fuel consumption per unit shipped, and necessitates proper disposal after use. By reducing packaging weight by 175 grams per unit, Hewlett Packard and was able to augment the number of units on a pallet from 300 to 720 for one of its camera products.

3) Product utilization and End of Life: Although spaced out from the producer, the environmental impacts from product use and removal are very imperative. Green 
International Journal of Managing Value and Supply Chains (IJMVSC) Vol. 3, No. 4, December 2012

companies should keep in mind that their products may go through numerous customers after they sell it and should assess the impact of the product's total life cycle. For example, Xerox recognized parts in its copiers that could be used again in new machines. By scheming products to take gain of these parts, Xerox evaded purchasing new parts and saved several hundred million dollars a year. This had the added advantage of saving customers the burden of spacing out older machines, which earned Xerox elevated customer loyalty.

4) Implementing a Greener Supply Chain: After a lucid vision on green supply chain and of its products' environmental impacts a producer company should take actions to accomplish that vision. It is imperative to retain a life cycle outlook of the product when undertaking this step. The aim should be to green the entire supply chain, not just the impact of one step. Going green is not a one-time proposal, but a continuous effort to recognize ways to diminish a company's environmental impact and improve business standards.

\section{GSCM- Optimum Business Results ARe Possible Through LONGTERM PRACTICES}

Greening the supply chain requires long-term dedication. Green supply chain implementation is a multi-year program which requires considerable resource investment even if companies have an eco friendly culture. Many lucrative firms such as Herman Miller, Hewlett Packard, Timberland, and Xerox have fruitfully implemented green supply chain management practices. For these companies, going green is not just a slogan, it is an integral part of their business strategy; they link sustainable programs to reducing costs, increasing revenue, and mitigating risks. GSCM should emphasize the issues on:

1) Aligning green supply chain goals with business goals

2) Evaluating the supply chain as a single life cycle system

3) Using green supply chain analysis as a catalyst for innovation

4) Focusing on source reduction to reduce waste

\section{CASE STUdies ON GSCM (INTERNATIONAL)}

\subsection{The Dutch flower industry greened its production to increase throughput}

Problem: Netherlands produces $65 \%$ of the worlds' cut flowers, yet has limited land. Accumulation of cultivation in a cramped area resulted in fertilizer, herbicide, and pesticide contamination.

Solution: To correct the problem, cultivation was shifted to rock wool and water instead of soil. Fertilizer content in the water is thus recycled and waste gets reduced. Water based growth also condenses the threat of pestilence by weeds and pests, plummeting the need for chemical treatments. The new system reduced variations in growth and greatly improvised the output. Producers were also able to increase output and reduce costs through new harvesting methods.

\subsection{Bank of America provides evidence for coexistence of eco-friendly manoeuvre with company's growth.}

Problem: Increased cutting down of trees for paper production. Two out of three households are Bank of America customers that lead to a lot of paper use/waste.

Solution: The bank's "Bank Greener, Live Greener" initiative is taken through a partnership with The Nature Conservancy. Customers are encouraged to manage their accounts and receive, view and pay bills entirely online. By using paperless services like online account statements, bill pay and e-bills customers have saved more than 8,000 tons of paper since 2004. 


\subsection{Coke and sustainable packaging}

Problem: Increased consumption of non-sustainable packaging material and energy.

Solution: In order to make packaging a valuable resource for future use:

a. REDUCE Efficient usage of material and energy in packaging.

b. RECOVER Approximately 50\% of the recyclable bottles and cans are recovered.

c. REUSE Purchasing products that are made from recycled packaging material and increasing the efficiency of the refillable bottles.

\section{GREEN EVOLUTION - CASE STUDIES (INDIA)}

Increasingly, Indian companies are adopting 'green practices'. It helps the environment as well as their business. Indian Companies have sensed the demands to go green, as many of their Western counterparts are building environmental sustainability as a business ethic. For example, Wal-Mart, which imports over $\$ 3$ billion in goods annually from Indian suppliers, recently asked them to adopt green practices or risk of losing the retail giant as a customer.

To reduce fuel consumption, companies can reconfigure their physical network to locate suppliers, manufacturing and customers close to each other. For Indian companies, there are many compelling reasons to develop environmentally conscious practices. It is needless to mention that leading companies know, by going green in the right manner, helps them augment and sustain their wealth. Here are a few instances:

- To overcome increasing electricity costs that became a huge burden on the profits of Tulsi Tanti's textile business, he developed a wind energy system. That idea changed his focus and he switched over to energy production and today his company, Suzlon Energy, is one among the largest wind-turbine makers in the world.

- Realising a need in the market, the Maini Group launched Reva, an electric car that has an increasing customer adoption in India today. Reva has received a good response in European customers as well.

- Rahul Bajaj set up a wind-power generation system that today provides $90 \%$ of his plants' energy needs, while realising savings of $\$ 5$ million annually.

- Nokia, India is going ahead with take-back and recycling activities in 2008 and is running over 1400 permanent recycling points at their Care and Retail outlets. The 'Planet Ke Rakhwaale' take-back initiative was extended to 28 cities across India in September 2009 and became a nation-wide recycling campaign in January 2010. Recycling awareness related activities were carried out at all Nokia Care Centres and Priority Dealers. The campaign, supported by an extensive media campaign, aimed to inspire young minds to spread the recycling message. For every handset, regardless of the brand, dropped in the recycle bin, Nokia promised to plant a tree and also offered a surprise gift. Under this initiative nearly 1, 00,000 trees have been planted in different parts of India by various NGOs.

\section{WHY INDIA LAGS BEHIND?}

In a country of 1.2 billion inhabitants, the figures are quite extraordinary and so are the challenges:

- Serious infrastructure deficit from lack of roads and road maintenance;

- Absence of deep sea ports and lack of port handling equipment;

- Endemic road traffic and airport congestion,

- Negligible use of alternative cargo transport modes such as rail, coastal or inland waterways; 
- The highly fragmented, multifaceted and uncertain set of laws governing trade licences, import/export and taxes.

- Lack of awareness,

- Illiteracy and absence of knowledge about 'green world'

When the supply chain perspective changes with emphasis put on the ways to compute the environmental impact of any activity, companies can focus efforts on the biggest issues first based on the assumption that which is measured can only improve. All the initiatives aimed at plummeting energy or material utilization are likely to be positive for the base levels. But sometimes, initiatives are unsatisfactory due to poor performance of technology. Since majority of Indian companies are strictly profit based, cost-cutting becomes a serious issue.

\section{HOW TO IMPROVE THE SITUATION IN INDIA?}

After doing an extensive research on various scenarios in India with respect to sustainable and green supply chain management and also considering successful cases across the globe, we came across few points which are highlighted in Table 1.

TABLE 1: GREEN SCM- SETBACKS \& SOLUTIONS

\begin{tabular}{|c|c|c|}
\hline Problem & Key opportunity & Solution \\
\hline Transport & $\begin{array}{l}\text { *India has one of the largest } \\
\text { railway network }\end{array}$ & $\begin{array}{l}\text { *Bulk transportation, use of trains } \\
\text { Vs trucks }\end{array}$ \\
\hline $\begin{array}{l}\text { Expensive } \\
\text { Package }\end{array}$ & $\begin{array}{l}\text { *Middle class Indian consumers } \\
\text { are not affected by expensive and } \\
\text { attractive packaging. Price is a } \\
\text { major issue. Highly fragmented } \\
\text { packaging is also not appreciated. } \\
\text { *Bulk packaging is still in its } \\
\text { growth phase. }\end{array}$ & $\begin{array}{l}\text { *Instead of focusing on quality } \\
\text { packaging, focus on quantity } \\
\text { packaging i.e. reduces the trend } \\
\text { towards fragmented packaging, e.g. } \\
\text { introducing Rs. } 10 \text { Shampoo sachets } \\
\text { instead of Re.1 / Rs. } 2 \text { sachets. } \\
\text { *Instead of container based } \\
\text { products, use more and more } \\
\text { refillable products. }\end{array}$ \\
\hline $\begin{array}{l}\text { Excessive use } \\
\text { of non- } \\
\text { biodegradable } \\
\text { items (plastic } \\
\text { etc) }\end{array}$ & $\begin{array}{l}\text { *Even though plastics below } 40 \\
\text { microns are banned in India, in } \\
\text { common man's eyes it is just } \\
\text { another bureaucratic affair. } \\
\text { * No legal provision in India } \\
\text { against plastic littering. }\end{array}$ & $\begin{array}{l}\text { *There are many alternatives to } \\
\text { plastics, like plant sources which are } \\
\text { renewable. } \\
\text { *Littering should be made a heavy } \\
\text { punishable offence or the offenders } \\
\text { must be held up for community } \\
\text { services by litigation. } \\
\text { * Levy of spot-fines would enhance } \\
\text { Cleanliness consciousness. }\end{array}$ \\
\hline $\begin{array}{l}\text { Lack of } \\
\text { effective } \\
\text { recycling }\end{array}$ & $\begin{array}{l}\text { *In India, less than } 5 \% \text { e-waste } \\
\text { gets recycled owing to the lack of } \\
\text { proper infrastructure, legislation } \\
\text { and framework. } \\
\text { *The organized sector contributes } \\
\text { to a lean proportion of the } \\
\text { recycling business. }\end{array}$ & $\begin{array}{l}\text { *Over } 90 \% \text { of e-waste generated in } \\
\text { India is managed by the unorganized } \\
\text { sector and scrap dealers in this } \\
\text { market dismantle the disposed } \\
\text { products instead of recycling it. } \\
\text { *However, is a vast scope of growth } \\
\text { if the recyclers and suppliers engage } \\
\text { with IT giants and other enterprises } \\
\text { for effective e-devices disposal }\end{array}$ \\
\hline
\end{tabular}


International Journal of Managing Value and Supply Chains (IJMVSC) Vol. 3, No. 4, December 2012

\begin{tabular}{|c|c|c|}
\hline $\begin{array}{l}\text { Transportation } \\
\text { leading to } \mathrm{CO} 2 \\
\text { emission }\end{array}$ & $\begin{array}{l}\text { *Also, with the advent of cheaper } \\
\text { and smaller cars like the Nano, } \\
\text { motorization is expected to } \\
\text { continue to increase at an } \\
\text { unprecedented rate. }{ }^{*} \text { Most people } \\
\text { in the cities have an increasing } \\
\text { propensity to use light-duty } \\
\text { vehicles as their main mode of } \\
\text { daily commute, partially because } \\
\text { of disintegrated, uncomfortable, } \\
\text { and old public transport systems. }\end{array}$ & $\begin{array}{l}\text { *Carbon Capture and Storage (CCS) } \\
\text { technology- It works in the } \\
\text { following manner-trapping and } \\
\text { separating CO2 from other gases, } \\
\text { transporting this captured CO2 to a } \\
\text { storage location, and storing that } \\
\mathrm{CO} 2 \text { far away from the atmosphere. } \\
\text { *The government should priorities } \\
\text { and invests sufficient funds in the } \\
\text { private sectors towards the urban } \\
\text { public transport system. }\end{array}$ \\
\hline
\end{tabular}

The Sustainable and Green Supply Chain Practices can be implemented at various phases of product development as depicted in Fig 1:

FIGURE 1: PHASES OF PRODUCT DEVELOPMENT

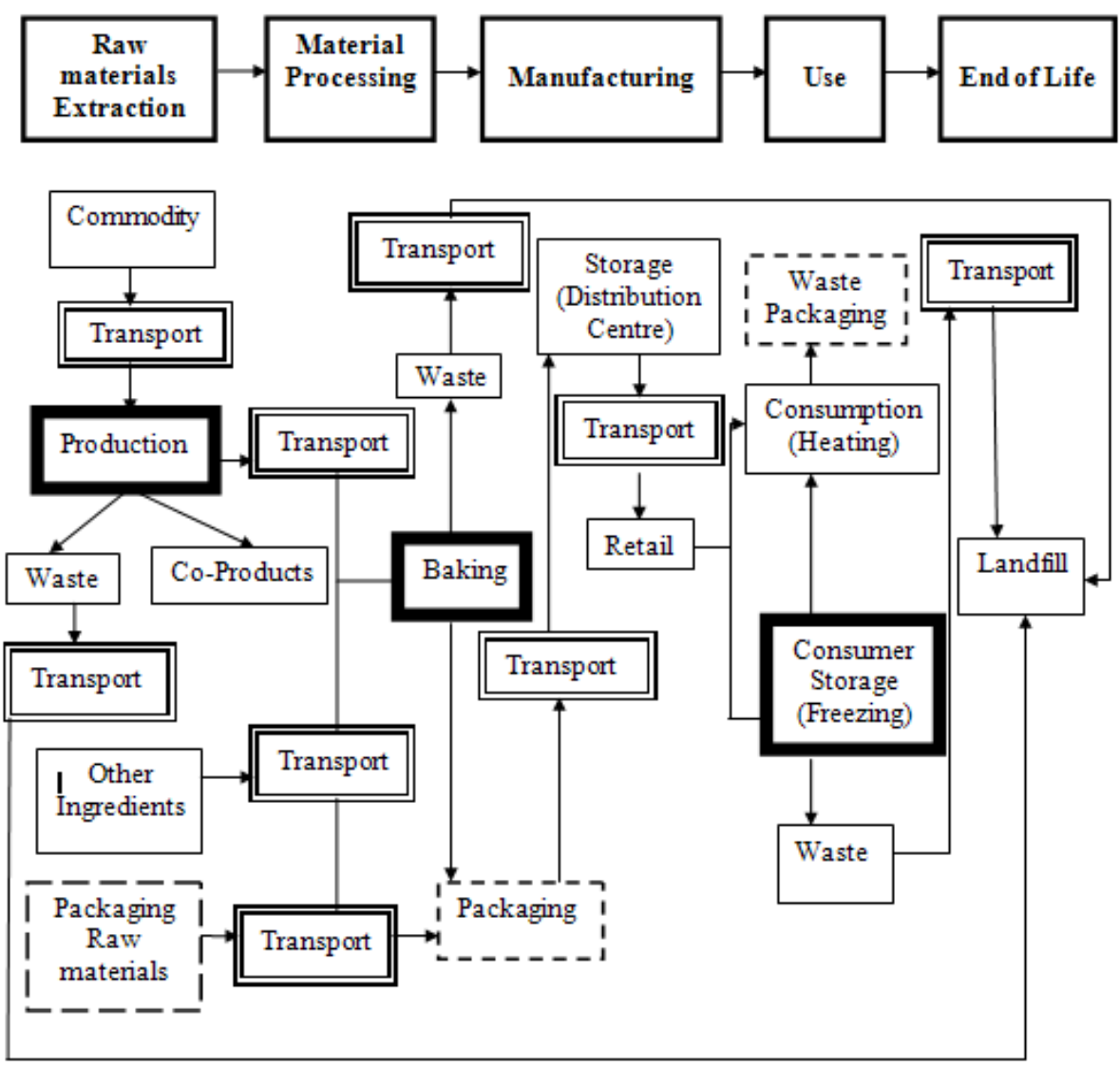




\section{STEPS To GREen A COMPANY'S SUPPLy Chain}

- Eliminate supply chain steps

- Reduce expensive packaging materials

- Implement more efficient or cleaner processes

- Improve energy efficiency of facilities and equipment

- Create standard cost effective and lighter packaging for goods with a short shelf life.

- Utilize biodegradable packaging, made from recycled material.

- Sort recyclable materials as precise as possible to make best use of quantity and returns

- Work with regional recycling experts to reduce transportation costs of reusable materials.

- Recycle material in a prompt manner to enhance market feasibility.

- Instruct and persuade the entire organization to contribute to "green" causes.

\section{OTHER SOLUTIONS}

\section{Reverse Logistics}

Reverse logistics denotes a set of planning execution and flow control measures for raw materials and finished products, with the aim of recovering and recycling the products or materials and ensures that the products are returned from the user to the producer in order to be recycled. In this process, the chain is covered in the opposite direction. In India, lack of awareness of proper disposal of used products is an issue of great concern and as a result of this the environment suffers.

\section{Green Supply Chain Goals compatible with Business Goals}

Energy costs can be reduced by a reduction in consumption through increased usage of energy efficient and greener equipments. This can be initiated by the major key players in the industry.

\section{Green Supply Chain through Innovative Processes}

Indian companies do not often change their businesses processes and it is this attitude which allows inefficient processes to continue unabated causing unnecessary waste and pollution. For example, Japanese automakers capitalised ineffableness in the US automotive industry and became market leaders. Thus, greener business can prove to have a lot of impact on the profits.

\section{CONCLUSION AND FUTURE RESEARCH}

The present research represents the first attempt to summarize how some of the largest global companies are approaching sustainability and leveraging it as part of an overall business strategy. Using content analysis of corporate reports, we understand that the research is limited to companies' self-reported activities that have no priorities or quantitative measures. Unlike financial reports that have standard format and are mandated by regulatory agencies, sustainability reports range widely and include many different activities. It is essential to develop a validation mechanism or a quantitative measure that can be used to ensure what the reports say is consistent with what actually happens. This research also represents a static, positive perspective of what is happening now. To develop a better understanding of sustainability trends, one would want to engage in a longer term longitudinal study. There is also need for a comparative study between geographical areas, over long period of time, to truly 
International Journal of Managing Value and Supply Chains (IJMVSC) Vol. 3, No. 4, December 2012

understand what the changes and gaps have been and why they exist. Finally, it would be interesting to see if there are differences between industry sectors (i.e. manufacturing vs. service-based industries) in their green supply chain activities.

\section{REFERENCES}

[1] Beamon, B.M. (1999). Designing the green supply chain . Logistics Information Management, 12, 332-342

[2] Bey, C. (2001). Quo vadis industrial ecology? Greener Management International, 34, 35-42.

[3] Chouinard, M., D’Amours, S. and Ait-Kadi, D.(2005). Integration of reverse logistics activities Within a supply chain information system. Computers in Industry, 56, 105-124.

[4] Das, J.K. (2002). Responding to green concerns: the role for government and business.Vikalpa, 27, $3-12$.

[5] Guide, V.D.R. and Van Wassenhove, L.N. (2002). The reverse supply chain. Harvard Business Review, 18, 25-26

[6] Hui, I.K., Chan, A.H.S. and Pun, K.F. (2001).A study of the environmental management system implementation practices. Journal of Cleaner Production, 9, 269-276

[7] Kaiser, B., Eagan, P.D. and Shaner, H. (2001).Solutions to health care waste: life-cycle thinking and 'green' purchasing. Environmental Health Perspectives, 109, 205-207

[8] Khoo, H.H., Bainbridge, I., Spedding, T.A. and Taplin, D.M.R. (2001). Creating a green supply Chain, Greener Management International, 35, 71-88.

[9] Lippmann, S. (1999). Supply chain environmental management: elements for success. Corporate Environment Strategy, 6, 175-182

[10] Porter, M.E. and van der Linde, C. (1995a).Green and competitive. Harvard Business Review, 73, 120-34

[11] Sarkis, Joseph, Q. Zhu, and Kee-hung Lai. (2011): "An organizational theoretic review of green supply chain management literature." International Journal of Production Economics 130(1) 1-15.

[12] Noor Aslinda Abu Seman, Norhayati Zakuan, Ahmad Jusoh and Mohd Shoki Md Arif (2012), "Green Supply Chain Management: A Review and Research Direction” International Journal of Managing Value And Supply Chains, Volume 3, Number 1

[13] Srivastava, Samir K. (2007) "Green supply-chain management: a state-of-the-art literature review" International journal of management reviews 9(1) 53-80.

[14] Arimura, T. H., Darnall, N., \& Katayama, H. (2011). Is ISO 14001 a gateway to more advanced voluntary action? The case of green supply chain management. Journal of Environmental Economics and Management, 61(2), 170-182.

[15] Chen, Y. J., \& Sheu, J. (2011). "Differential game for environmental regulation in green supply chain”,Supply Chain Management, 261-274.

[16] Tseng, M. L. (2011). Green supply chain management with linguistic preferences and incomplete information. Applied Soft Computing, 11(8), 4894-4903 